\title{
KARAKTERISTIK GAMBAR BEBAS SISWA KELAS IV DAN KELAS IV SD NEGERI PARANGTAMBUNG 1
}

\author{
Mutmainnah \\ Prodi Pendidikan Seni Rupa, Fakultas Seni dan Desain Universitas Negeri Makassar \\ mutmainnahkarbiah@gmail.com
}

\begin{abstract}
Abstrak
Penelitian ini bertujuan untuk memperoleh data yang akurat tentang karakteristik gambar bebas siswa kelas IV dan kelas V SD Negeri Parangtambung 1. Populasi yang digunakan pada penelitian ini adalah siswa kelas IV dan kelas V dengan jumlah 51 orang siswa. Teknik pengumpulan data dilakukan dengan cara observasi dan dokumentasi. Data yang diperoleh dari teknik pengamatan dan dokumentasi dianalisis secara kualitatif. Hasil penelitian terhadap gambar bebas siswa SD Negeri Parangtambung 1 yang diperoleh dari jumlah siswa sebanyak 51 siswa. Dari seluruh jumlah siswa yang diteliti, diperoleh beberapa macam karakteristik yang timbul dari gambar bebas yang diciptakan yaitu karakteristik berdasarkan tema/objek pemandangan dengan jumlah sebanyak 32 siswa, berdasarkan tema bangunan dengan jumlah sebanyak 12 siswa, berdasarkan objek kartun dengan jumlah sebanyak 2 orang. Berdasarkan objek tanaman dengan jumlah sebanyak 4 siswa. Berdasarkan dari aspek warna lebih dominan menggunakan warna hijau untuk pewarnaan gunung dan biru untuk pewarnaan laut.Berdasarkan dari aspek garis yang lebih sering digunakan adalah garis horizontal. Berdasarkan dari aspek form atau bentuk, pada penggambaran objek gunung ada dua bentuk yaitu dibuat runcing seperti segitiga, dan digambarkan seperti setengah lingkaran. Diperoleh 7 siswa yang memasuki tahap perkembangan masa prabagan, 39 siswa yang memsuki tahap perkembangan masa bagan, dan 2 siswa yang memasuki tahap perkembangan awal realisme semu.
\end{abstract}

Kata Kunci: Karakteristik; Gambar Bebas;

\section{PENDAHULUAN}

Anak adalah sosok manusia yang diciptakan dengan berbagai tahap pertumbuhan.Setiap anak memiliki karakter atau kreatifitas yang berbeda- beda. Pada usia dini, anak memerlukan bimbingan untuk pertumbuhan mental yaitu pertumbuhan intelektual atau berpikir dan pertumbuhan fisik.

Semua anak memiliki karya seni yang bersifat alamiah, ekspresif, dan dinamis. Karakteristik ekspresif seni rupa anak sangatlah beragam.Dalam berekspresi, anak selalu menuangkannya dalam menggambar karena menggambar kita dapat melihat karakteristik anak pada saat sedang mengalami pertumbuhan.Biasanya anak mengungkapkan perasaan dalam menggambar karena menggambar kita dapat melihat karakteristik anak pada saat sedang mengalami pertumbuhan. Biasanya anak mengungkapkan perasaan, keinginan, emosi, pengalaman, dan fantasinya ke dalam gambar sehingga dapat disimpulkan bahwa karya gambar anak menggunakan media komunikasi dalam bergaulan lingkungannya.

Ketika anak berusia 2-4 tahun, karyakaryanya masih belum stabil. Kadang hanya merupakan goresan tanpa bermaksud menggambar sesuatu, melainkan hanya gerakan tangan yang melemaskan otot. Gambar tersebut hanya berupa garis-garis. Gambar anak usia 2 sampai 4 tahun mempunyai sifat yang berbeda walaupun pada umumnya sama. Perbedaan wujud serta prinsip tersebut dipengaruhi oleh faktor eksternal dan internal (Hajar Pamadhi dkk, 2008: 125-129), yaitu: 1) Faktor Eksternal adalah faktor luar seperti pengamatan guru, atau anak terhadap dunia dan objek nyata serta pengaruh kehidupan sosial orang tua dan masyarakat sekelilingnya; 2) Faktor internal merupakan faktor yang berkembang secara otomatis, seiring dengan perkembangan tubuh dan mentalnya. Faktor ini tidak kelihatan akan tetapi secara substansi dapat mempengaruhi pikiran anak misalnya cara berpikir, dan berkomunikasi dengan orang lain. 
Menilai suatu gambar anak usia 2 tahun s.d 12 tahun dan remaja usia 13 tahun s.d 17 tahun tidak mudah seperti yang kita duga, dimana pertimbangan jiwa anak orangperorang adalah demikian unik. Hal ini karena setiap anak memiliki tata ungkapan yang berbeda-beda antara seorang anak dengan yang lainnya. Gambar anak dapat mencerminkan karakter masing-masing, apa yang digambarkan merupakan hasil apa yang di lihat dan atau dirasakan. Apa yang digambar bukan hanya yang sedang ia pikirkan, melaikan apa yang dilihat dengan perasaan yang diasosiasikan. Dalam menggambar, anak dapat meniru alam, mengubah, mengurangi, atau menghilangkan sebagian objek yang digambarkannya.

Dalam pertumbuhan anak, dapat dilihat karakter-karakter yang berbeda yang timbul dari dalam jiwa anak, sudah tidak lazim lagi sering kita jumpai anak yang masih berumur 4-6 tahun tetapi karyanya yang berupa gambar bebas sudah mampu melebihi karya anak yang sudah berusia 12-14 tahun. Dalam menggambar, si anak sudah mampu memperhitungkan gelap terang, persfektif, dan bentuk proporsi benda. Ini disebabkan karena si anak selalu mendapatkan pembinaan dan dorongan baik fisik maupun mental dari orang tua maupun di sekitar lingkungan tempat tinggalnya. Akan tetapi banyak juga yang sering kita jumpai anak yang sudah berumur 12 tahun, tetapi hasil

karyanya masih digolongkan dalam karya anak yang bersifat coreng-moreng yang gambarnya berupa coretan-coretan atau kumpulan beberapa garis saja. Padahal dalam usia demikian si anak sudah bisa mengontrol gerakan-gerakan tangannya. Kejadian seperti ini biasanya terjadi karena kurangnya bimbingan dan perhatian dari orang tua maupun lingkungannya. Atau bisa saja si anak tersebut mengalami keterbelakangan mental.

Dengan adanya lembaga pendidikan yang dikenal dengan sekolah, maka akan memudahkan anakanak untuk lebih bebas mengekspresikan karya- karyanya. Sehingga orang tua tidak perlu cemas akan pertumbuhan fisik maupun mental si anak.

Pada umumnya, seorang siswa memiliki kemampuan yang berbeda dengan anak lainnya. Hal ini dapat dilihat dari sikap dan perilakunya baik di sekolah maupun di lingkungan keluarga. Di dalam pengembangan kreatifitas seorang siswa, tidak hanya guru yang sebagai pengajar di sekolah yang harus berperan aktif tetapi peranan orang tua juga dibutuhkan karena setiap anak ada yang memiliki kemampuan di bawah rata-rata atau dengan kata lain proses berfikirnya sangat lambat dan ada pula siswa yang memiliki kemampuan di atas rata-rata atupun proses berfikirnya sangat cepat.

Kemampuan anak dalam menggambar bebas khusunya siswa di sekolah dasar (SD), juga dapat dipengaruhi oleh proses pembelajaran yang diberikan oleh guru mata pelajaran Seni Budaya dan Keterampilan maupun guru dari bidang studi lain. Masalah ini dapat membuat kemampuan seorang anak dalam menggambar menjadi terhambat, karena bimbingan dari seorang guru yang memiliki kemampuan dalam pelajaran yang lain sangat berbeda dengan seorang guru yang memang sudah menguasai mata pelajaran Seni Budaya dan Keterampilan, khususnya dalam menggambar bebas.

Seperti yang kita ketahui, anak adalah sosok manusia yang sangat mungil, lucu, dan mempunyai pikiran yang masih kekanakkanakan. Akan tetapi di dalam sosok mungil itu ada jiwa dan raga yang mengalami pertumbuhan secara bertahap. Oleh karena itu, dalam penelitian ini akan dibahas tentang masalah karakteristik gambar bebas siswa pada siswa Sekolah Dasar Negeri Parangtambung 1.

\section{METODE PENELITIAN}

Penelitian ini merupakan penelitian content analysis (analisis isi) untuk mengamati karakteristik gambar bebas siswa kelas IV dan kelas V SD Negeri Parangtambung 1. Dilihat dari sifatnya, penelitian ini merupakan penelitian deskriptif, yaitu untuk mendeskripsikan karakteristik gambar bebas siswa dilihat dari teknik analisis datanya. Penelitian ini merupakan penelitian kualitatif.

Penelitian ini akan dilakukan di sekolah SD Negeri Parangtambung 1. Penelitian yang dilakukan terfokus pada siswa kelas IV dan kleas V SD Negeri ParangtAMBUNG 1 yang berlokasi di Kecamatan Tamalate, kota makassar, prov. Sulawesi Selatan. 
Variabel karakteristik terpercaya tentang masalah karakteristik dalam karya seni menggambar bebas siswa kelas IV dan kelas V SD Negeri Parangtambung 1.Adapun variabel penelitiannyayaitukarakteristik gambarbebas siswa kelas IV dan kelas V SD Negeri Parangtambung 1

Desain penelitian merupakan strategi mengatur setting penelitian dan dibuat sebagai kerangka acuan dalam melaksanakan penelitian.Agar penelitian ini dapat terlaksana dengan baik dan mudah, maka desain harus disusun dengan baik dan terencana.Untuk lebih jelasnya, pada penelitian tentang masalah Karakteristik Gambar Bebas Siswa Kelas IV dan kelas V SD Negeri Parangtambung1.Maka selanjutnya penelitian ini dilakukan dengan mengikuti desain penelitian di atas.

Sesuai dengan judul penelitian ini yaitu Karakteristik Gambar Bebas Siswa Kelas IV dan kelas V SD Negeri Parangtambung 1, maka variabel yang akan diteliti, akan di defenisikan secara operasional yaitukarakteristik gambar yaitu karakteristik tercermin pada karya anak dalam hal: tema/obyek, garis, warna, form, dan tahap perkembangan antara masa bagan (7-9 tahun) dan masa awal realisme (9-12 tahun)

Dalam penelitian ini ditetapkan populasi penelitian yaitu karya gambar bebas siswa kelas IV dan V SD Negeri Parangtambung 1 yang berjumlah 51 gambar. Dalam penelitian ini, penulis menggunakan teknik Total Sampling.Menurut Sugiyono (2013:124) total sampling adalah teknik penentuan sampel dengan cara mengambil seluruh anggota populasi sebagai responden atau sampel. Karena populasi yang akan diteliti memiliki karakteristik atau sifat pengungkapan dalam menggambar yang berbeda. Sehingga dalam penelitian ini,

penulis menetapkan anggota populasinya yang memiliki karakteristik sebagai sampel. Sebagai kesimpulannya, sampel yang akan digunakan mengambil sejumlah karya gambar bebas anak kelas IV dan kelasV SD Negeri Parangtambung 1 yang berjumlah 51 siswa.

Adapun jenis alat dan teknik pengumpulan data yang digunakan oleh peneliti dalam penelitian ini, yakni: Teknik observasi merupakan penelitian yang dilakukan dengan cara mengadakan pengamatan terhadap karya siswa untuk menganalisis karakteristik gambar bebasnya.

Teknik dokumentasi ini dilakukan untuk memperoleh data dokumentasi berupa gambar atau foto. Data yang diperoleh merupakan data yang dapat menunjukkan proses dan hasil penelitian. Alasan pemilihan cara ini dianggap sebagai salahsatu cara untuk memperoleh data secara tepat, cepat dan efisien.

Teknik analisis yang digunakan dalam penelitian ini adalah deskriptif kualitatif dengan taraf objektif. Analisis data merupakan proses penyusunan data yang diperoleh agar dapat ditafsirkan, digolongkan dalam suatu pola tertentu dengan mencantumkan suatu kode sesuai dengan kategorinya. Lalu diinterpretasikan, agar data yang terkumpul tidak menumpuk, kemudian disusunsistematis, sehingga memberikan gambaran yang bermakna tentang masalah yang sedang diteliti. Data yang telah dikumpulkan dan diproses kemudian disusun ke dalam teks yang diperluas dan dianalisis yang terdiri atas tiga alur kegiatan, yakni: reduksi data, penyajian data, dan penarikan kesimpulan atau verifikasi. Hal ini dimaksudkan untuk memperoleh gambaran yang dapat dipenuhi secara jelas dan terarah yang berkaitan dengan karakteristik gambar bebas siswa SD Negeri Parangtambung 1.

\section{HASIL DAN PEMBAHASAN 3.1. Hasil}

Didalam bab ini akan dibahas hasil penelitian yang telah dilakukan selama penelitian berlangsung tentang karakteristik gambar bebas siswa kelas IV dan kelas V SD Negeri Parangtambung 1.

Berikut uraian mengenai karakteristik dan pola perkembangan. lukisan siswa kelas IV dan kelas V:

\subsubsection{Karakteristik dan pola perkembangan lukisan kelas IV}

\subsubsection{Karya Fita Pus.P.S}

Karya Fita menggambarkan tema pemandangan. Lukisan ini dibuat dengan 
menggunakan pensil warna. Dalam lukisan ini digambarkan sebuah gunung, taman bermain, rumah, bunga, awan, matahari, pohon dan sekelompok burung yang terbang menjadi subjek pendukung. Pada penggambaran objek bunga terjadi pengulangan bentuk. Penggunaan warna pada gunung menggunakan warna hijau tua.Pada background gunung dia menggunakan warna orange seperti warna langit sunset.Terdapat pula matahari yang di gambar melingkar dan diberi warna kuning.Awannya pun diberi warna orange seperti warna langit.Garis yang digunakan adalah garis lurus, dan garis lengkung beraturan.volume gambarnya sudah cukup bagus karena permukaan kertas dipenuhi dengan gambar dan warna. Secara visual, gambar anak ini memasuki tahap perkembangan bagan.

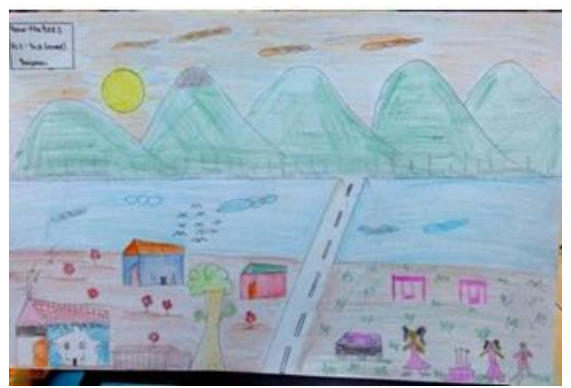

Gambar 1. "Pemandangan Alam", Karya Fita Pus.P.S, 9 tahun, Kelas IV sekolah dasar.

(Dokumentasi: Mutmainnah, Mei 2018)

\subsubsection{Karya Siti Hajra Pratiwi (9 tahun)}

Karya Siti Hajra Pratiwi menggambarkan tema pemandangan. Objek gunung di buat seperti setengah lingkaran dan diberi warna hijau. Pada pojok kanan ia menggambarkan objek pantai dan diberi warna biru. Terdapat binatang laut di dalamnya seperti ikan. Pada objek ikan terjadi pengulangan bentuk dan dibuat tembus pandang atau transparan. Di pojok kiri digambarkan objek pohon yang batangnya diberi warna coklat. Terdapat pula objek rumah, pagar, dan sepetak sawah. Garis horisontal digunakan sebagai pemisah antara objek gunung dengan objek yang lainnya. Pada pojok kanan atas digambarkan objek matahari yang bersinar diberi warna kuning. Pada background langit di gambarkan tiga bentuk awan yang diberi warna biru. Secara visual, lukisan Siti Hajrah masih berada pada tahap perkembangan bagan.

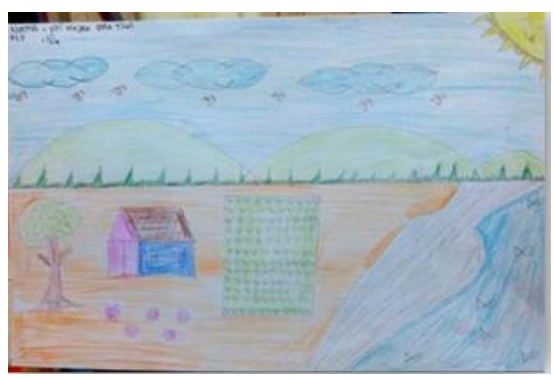

Gambar.2 "Pemandangan Alam", Karya Siti Hajra Pratiwi, 9 tahun. (Dokumentasi: Mutmainnah, Mei 2018)

\subsubsection{Karya Febrianti (9 tahun)}

Karya Febrianti menggambarkan tema pemandangan. Objek gunung dibuat runcing seperti segitiga dan garis horizontal digunakan sebagai pembatas antara gunung dengan objek lainnya.Di atas garis horizontal digambarkan rumput.Pada pojok kanan bawah ia menggambarkan objek pantai yang terdapat binatang laut seperti ikan di dalamnya hal ini juga tampak pada karya Siti Hajra Pratiwi (lihat gambar 10). Objek ikan digambarkan secara transparan. Di antara objek pantai dan objek rumah terdapat jalan yang digambarkan menggunakan garis zigzag. Penggunaan warna lebih dominan adalah warna hijau pada pewarnaan gunung. Disekitaran objek rumah tidak diberi warna, yang diwarnai hanya sepetak sawah, pagar, dan batang pohon saja. Volume gambarnya belum cukup bagus karena masih banyak ruang yang tidak dimanfaatkan dengan baik.Jika dilihat, gambar anak ini memasuki tahap perkembangan bagan.

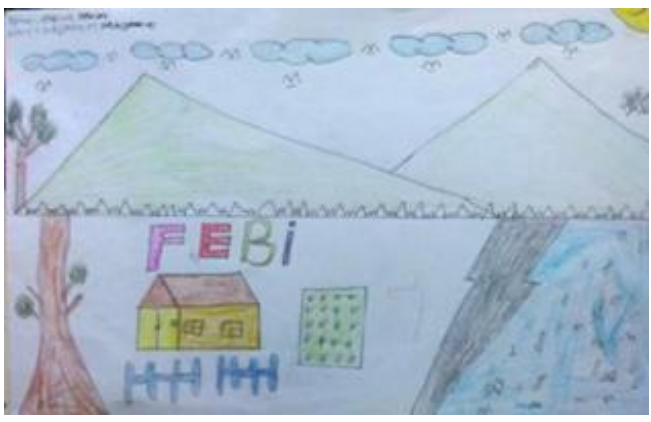

Gambar.3 "Pemandangan Alam", karya Febrianti, 9 tahun.(Dokumentasi: Mutmainnah, Mei 2018) 


\subsubsection{4. karya Fausan AlKahfi (8 tahun)}

Karya Fausan Alkahfi menggambarkan tema pemandangan.Objek gunung ada 3 buah dan dibuat runcing seperti segitiga. Objek gunung diberi warna hijau. Pada background gunung langitnya diberi warna biru dan digambarkan objek awan dan burung. Dipojok kanan atas digambarkan matahari yang bersinar diberi warna kuning. Pemberian gelap terang pada batang pohon, dari coklat tua ke coklat muda, menunjukkan bahwa dia sudah sedikit mengerti tentang penggunaan gelap terang.Begitupun pewarnaan pada rumput yang ada di bawah pohon, jadi kesannya pohon yang di gambar tidak melayang. Dipojok kiri bawah digambarkan objek pantai dan objek ikan. Objek ikan dibuat tembus pandang atau transparan. Pewarnaan pada pantai ia memberikan dua warna yaitu biru tua dan muda, kesannya air yang diberi warna biru tua menandakan kedalaman. Secara visual, gambar anak ini memasuki tahap perkembangan bagan.

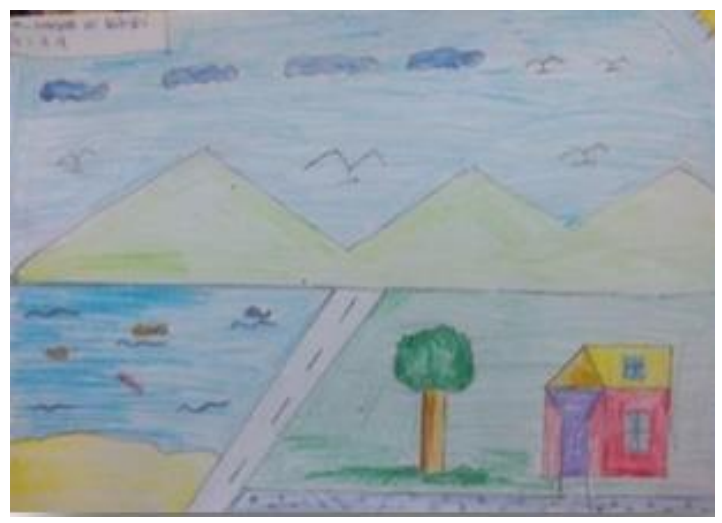

Gambar.4 "Pemandangan Alam". Karya Fausan Alkahfi, 8 tahun. (Dokumentasi: Mutmainnah, Mei 2018)

\subsubsection{Karya Muh.Wahyudi. (9 tahun)}

Karya Muh.Wahyudi menggambarkan tema pemandangan.Garis horisontal digunakan sebagai pemisah antara objek gunung dengan objek yang lainnya. Pada objek gunung digambari beberapa pohon di atasnya dan satu rumah. Disebelah kanan jalan digambarkan lapangan yang diberi warna hijau, tanah yang diberi warna kuning dan rumputnya diberi warna hijau, dan beberapa sawah yang diberi warna kuning. Objek orang yang ada di lapangan, objek rumput, dan tanaman padi mengalami pengulangan bentuk. Disebelah kiri bawah digambarkan dua buah rumah yang diberi warna biru dan merah dan dua buah pohon. Secara visual, gambar anak ini memasuki tahap perkembangan bagan.

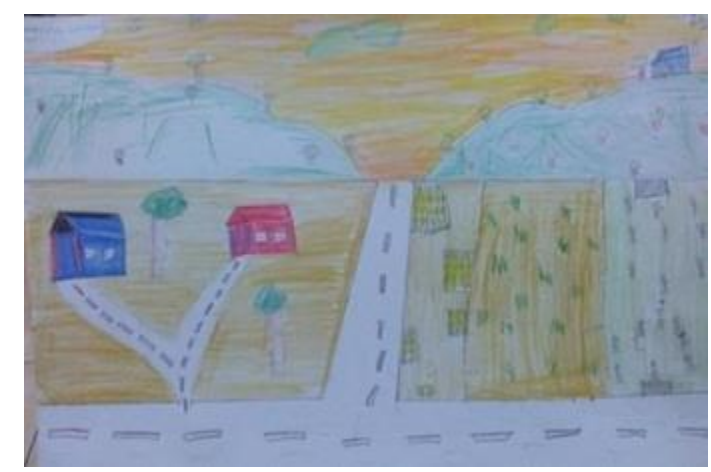

Gambar.5 "Pemandangan Alam", karya Muh.Wahyudi, 9 tahun. (Dokumentasi: Mutmainnah, Mei 2018)

\subsection{Pembahasan}

Dapat dilihat dari hasil penelitian siswa kelas IV dan kelas V ternyata setiap siswa pada usia yang berbeda-beda memiliki sifatsifat yang berbeda pula. Namun banyak juga kesamaan yang ditemui. Terdapat kesamaan dan perbedaan yang tercermin pada sifat-sifat yaitu ekspresi, melebih-lebihkan, dan naratif. Gambar anak cenderung untuk menggambarkan secara berlebih-lebihan dari objek yang dianggapnya penting. Objek atau bagian dari suatu objek yang di anggap penting digambarkan secara lebih menonjol dari segi ukuran yang dibandingkan dengan objek atau bagian objek lainnya sehingga gambar anak tampak tidak proporsional. Gambar anak pada dasarnya adalah ceritera anak tentang diri dan lingkungannya. Tidak mengherankan bila gambar anak menghadirkan tema-tema yang disenangi oleh anak. Mulai timbul minat yang berbeda antara anak laki-laki yang senang menggambarkan hal-hal heroik semacam perang, tokoh superman, atau olahraga. Sementara anak perempuan sering menggambarkan hal-hal yang mencerminkan kelembutan seperti bunga- bungaan dan semacamnya. 
Pada karya siswa terdapat berbagai tingkatan perkembangan ungkapan ekspresi anak yang diikuti dengan batasan usia yang berbeda-beda. Lowenfield dan Brittain membagi masa perkembangan karya seni rupa anak (Widia Pekerti dkk, 2005:924) yaitu masa coreng-moreng (2-4 tahun), masa prabagan (4-7 tahun), masa bagan (7-9 tahun), masa awal realisme (9-12 tahun), masa realisme semu (12-14 tahun), masa dewasa (14-17 tahun). Berikut uraian tentang karakteristik gambar dan pola perkembangannya.

\subsubsection{Karakteristik gambar dan pola perkembangan di kelas IV.}

\subsubsection{Karakteristik gambar siswa ditinjau dari segi tema atau objek.}

Karakteristik gambar siswa ditinjau dari segi tema diperoleh data 22siswa yang menggambar tema pemandangan, 1 siswa yang menggambarkan tema pemandangan laut, 1 siswa yang menggambarkan objek pohon, dan 1 siswa yang menggambarkan objek kartun.

\subsubsection{Karakteristik gambar siswa ditinjau dari segi form atau bentuk}

Karakteristik gambar siswa ditinjau dari segi form atau bentuk diperoleh siswa yang menggambarkan tema pemandangan ada 22 siswa.Dari hasil penelitian diperoleh bentuk gunung yang berbeda-beda.5 diantaranya menggambarkan bentuk gunung runcing seperti segitiga, dan 16 diantaranya menggambarkan bentuk gunung seperti setengah lingkaran.

Dari hasil penelitian diperoleh data bentuk jalan yang berbeda beda. 17 diantaranya belum mengenal persfektif, dan 4 diantaranya sudah mulai mengenal persfektif.

\subsubsection{Karakteristik gambar siswa ditinjau dari segi garis.}

Karakteristik gambar siswa ditinjau dari segi garis diperoleh data hampir semua yang menggambarkan tema pemandangan menggunakan garis horizontal sebagai pemisah antara objek gunung dengan objek yang lain.

\subsubsection{Karakteristik gambar siswa ditinjau dari segi warna}

Karakteristik gambar siswa ditinjau dari segi warna diperoleh data hampir semua yang menggambarkan tema pemandangan warna yang lebih dominan digunakan pada pewarnaan gunung adalah warna hijau muda.Dan pewarnaan pada objek pantai dan langit lebih dominan menggunakan warna biru.

\subsubsection{Karakteristik gambar siswa ditinjau dari segitahap perkembangan.}

Karakteristik gambar siswa ditinjau dari tahap perkembangan diperoleh data 18 siswa yang memasuki tahap perkembangan masa bagan.Dan 7 siswa masih berada pada tahap perkembangan masa prabagan.

\subsubsection{Karakteristik gambar dan pola perkembangan di kelas $\mathbf{V}$.}

\subsubsection{Karakteristik gambar siswa di tinjau dari segi tema atau objek.}

Karakteristik gambar siswa ditinjau dari segi tema diperoleh data ada 10 siswa yang menggambar tema pemandangan, 3 siswa menggambarkan objek bunga, 12 siswa yang menggambarkan tema bangunan, dan 1 siswa menggambarkan objek kartun.

\subsubsection{Karakteristik gambar siswa ditinjau dari segi form atau bentuk.}

Karakteristik gambar siswa ditinjau dari segi form atau bentuk diperoleh siswa yang menggambarkan tema pemandangan ada 10 siswa. Dari hasil penelitian diperoleh bentuk gunung yang berbeda.1 diantaranya menggambarkan objek gunung runcing seperti segitiga, dan 9 diantaranya menggambarkan objek gunung seperti setengah lingkaran.

Dari hasil penelitian diperoleh siswa yang menggambarkan tema bangunan ada 12 
siswa. 11 siswa yang menggambarkan objek rumah yang hampir sama bentuknya dan 1 siswa yang menggambarkan objek mesjid.

Dari hasil penelitian diperoleh siswa yang menggambarkan objek bunga ada 3 siswa. 2 siswa diantaranya menggambar objek bunga yang ditanam di pot bunga dan 1 siswa yang menggambarkan beberapa bunga yang tumbuh di atas rumput yang luas.

\subsubsection{Karakteristik gambar siswa ditinjau dari segi warna.}

Karakteristik gambar siswa ditinjau dari segi warna pada tema pemandangan diperoleh data warna yang dominan digunakan adalah warna hijau pada objek gunung.Dan warna coklat digunakan pada pewarnaan tanah.

Karakteristik gambar siswa ditinjau dari segi warna pada tema bangunan diperoleh data warna yang dominan digunakan adalah warna biru.

Karakteristik gambar siswa ditinjau dari segi warna pada objek bunga diperoleh data warna yang lebih dominan digunakan adalah warna orange.

\subsubsection{Karakteristik gambar siswa ditinjau dari aspek garis.}

Karakteristik gambar siswa ditinjau dari aspek garis pada tema pemandangan diperoleh data ada 6 siswa yang menggunakan garis horizontal sebagai pemisah antara objek gunung dengan objek yang lain. Dan 4 siswa sudah tidak menggunakan garis horizontal pemisah antara objek gunung dengan objek yang lain.

\subsubsection{Karakteristik gambar siswa ditinjau dari aspek tahap perkembangan}

Karakteristik gambar siswa ditinjau dari segi aspek tahap perkembangan diperoleh data ada 24 siswa yang berada pada perkembangan masa bagan. Dan 2 siswa yang sudah memasuki masa awal realisme semu.

\section{SIMPULAN DAN SARAN 4.1. Kesimpulan}

Dapat dilihat dari hasil penelitian siswa

kelas IV dan kelas V ternyata setiap siswa memiliki karakteristik gambar dan pola perkembangan anak dalam menggambar bebas yang berbeda-beda. Sifat ekspresi gambar anak tercermin pada ide atau hasil penggambaran berdasarkan sudut pandang anak. Gambar anak cenderung untuk menggambarkan secara berlebih-lebihan dari objek yang dianggapnya penting.

Mulai timbul minat yang berbeda antara anak laki-laki yang senang menggambarkan hal-hal heroik semacam perang, tokoh superman, atau olahraga. Sementara anak perempuan sering menggambarkan hal-hal yang mencerminkan kelembutan seperti bunga- bungaan dan semacamnya. Hasil penelitian terhadap gambar bebas siswa SD Negeri Parangtambung 1 yang diperoleh dari jumlah siswa sebanyak 51 siswa. Dari seluruh jumlah siswa yang diteliti, diperoleh beberapa macam karakteristik yang timbul dari gambar bebas yang diciptakan yaitu karakteristik berdasarkan tema/objek pemandangan dengan jumlah sebanyak 32 siswa, berdasarkan tema bangunan dengan jumlah sebanyak 12 siswa, berdasarkan objek kartun dengan jumlah sebanyak 2 orang. Berdasarkan objek tanaman dengan jumlah sebanyak 4 siswa. Berdasarkan dari aspek warna lebih dominan menggunakan warna hijau untuk pewarnaan gunung dan biru untuk pewarnaan laut.Berdasarkan dari aspek garis garis yang lebih sering digunakan adalah garis horizontal. Berdasarkan dari aspek form atau bentuk, pada penggambaran objek gunung ada dua bentuk yaitu dibuat runcing seperti segitiga, dan digambarkan seperti tengah lingkaran. Diperoleh 7 siswa yang memasuki tahap perkembangan masa prabagan, 39 siswa yang memsuki tahap perkembangan masa bagan, dan 2 siswa yang memasuki tahap perkembangan awal realisme semu.

\subsection{Saran}

1. Dalam menggambar bebas sebaiknya guru kelas memperhatikan karakteristik pola perkembangan anak berdasarkan 
umur dan kelasnya pada setiap siswa SD Negeri Parangtambung 1.

2. Perlu ada pembinaan atau pelatihan bagi guru kelas tentang pengetahuan karakteristik gambar anak.

3. Bagi siswa yang masih kurang dalam menggambar seharusnya siswa tersebut lebih sering dilatih atau diberikan tugas tambahan.

\section{DAFTAR PUSTAKA}

Ali, Mohammad.1985. Penelitian Kependidikan Prosedur dan Strategi. Bandung : Angkasa

Francis. 2002. Menggambar Sebuah Proses Kreatif. Jakarta : Erlangga

Iskandar, 2018. Metodologi Penelitian Pendidikan dan Sosial. Jakarta : GP Prces.

Marjono, Dana.1990. Pendidikan Seni Rupa Untuk Sekolah Menengah Pertama. Bandung : Ganesha Exact.

Moeliono, Anton M (Ed). 1988. Kamus Besar Bahasa Indonesia . Jakarta : Departemen Kependidikan dan Kebudayaan RI.

Pamadhi, Hajar dkk. 2008. Seni Keterampilan Anak. Jakarta : Universitas Terbuka.

Salam, Sofyan.2001. Pendidikan Seni Rupa di Sekolah Dasar . Makassar : Badan Penerbit Universitas Negeri Makassar.

Sugiyono, 2013. Metode Penelitian Kuantitatif, Kualitatif dan $r$ dan $b$. Bandung : Penerbit Alfabeta.

Sukmadinata, N.S 2009. Metode Penelitian

Pendidikan.Bandung : UPI. 